\title{
乾電池亜鉊陰極に対するグルコン酸誘導体の防食効果
}

\author{
柴 䗁 安 一* 柴 森 成 二*
}

\section{Anticorrosive Effects of Gluconic Acid Derivatives on Zinc Anodes of Dry Cells}

\author{
Yasuichi Shibasaki and Seiji Shibamori
}

It was found by measuring weight losses of zinc specimens immersed different periods of time in the very slightly acid electrolytes of the zincmanganese dioxide dry cells that additions of small amounts of ammonium gluconate or gluconamide into the electrolyte were quite effective on the prevention of corrosion of zinc.

\section{1. 緒言}

極微酸性電解液を有する亜鉛二酸化マンガン乾電池の 鉛陰極は電解液に自然溶解しないで，放電中均一に理 論量だけ溶解するのが理想である。この理想に近ゔくた めに電解液組成を調節し，水銀塩を含有させることによ り亜鉛面にアマルガムを生成させて水素過電圧を大きく し，表面の性質を均一にしてかなりの効果をあげている が, なお不十分で, 種々の防食用添加剤が研究されてい る1 5)。

亜鉛への吸着力の大きい有機防食抄を添加すれば，亜 鉛の自然腐食をかなり防ぐことができるが，亜鉛面に吸 着した防食剂が不導体であるから放電中の亜鉛の溶解を 妨げ乾電池の内部抵抗が大きくなり放電性能が低下す る。そこで防食力は不十分でも放電性能低下の少ない防 食剂として水溶性防食戍が有望であろうと考え, グルコ ン酸アンモニウムおよびグルコン酸アミドを選び，亜鉛 に対する防食力を検討する。

\section{$2 \cdot 1$ 垔鉛試片}

\section{2. 供 試 試 料}

乾電池用覀鉛板 $(\mathrm{Zn} 99.8 \%, \mathrm{~Pb} 0.1 \%, \mathrm{Cd} 0.08 \%$, $\mathrm{Cu} 0.001 \%, \mathrm{Fe} 0.001 \%)$ から $1.2 \times 5.0 \times 0.03 \mathrm{~cm} \mathrm{の}$ 小片を切り取り, JIS $200 \sim 400$ 番の粒度の紙やすりで 表面を研摩し, 還流下のパークレンで脱脂し, 乾燥後直 ちに腐食試験に用いた。

その亜鉛試片の見掛表面積は $12.4 \mathrm{~cm}^{2}$, 重量は約 $1 \mathrm{~g}$ である。

その亜鉛試片を研摩後に熱処理, 表面層の溶解, その 他の処理などをしなかったので, 試片の表面層は腐食し 易い状態にあるわけであるが，そのまま実験に用いた。

\section{$2 \cdot 2$ グルコン酸アンモニウム}

Dーグルコン酸ソーダ水溶液と陽イオン交換樹脂とか らD-グルコン酸水溶液を造り，これにアンモニアガス を吹込んで得られた $D$-グルコン酸アンモニウムを再結 晶法 $\left(60^{\circ} \mathrm{C}\right.$ の水に飽和させ沪過し $1 \sim 3^{\circ} \mathrm{C}$ に冷却し結

\footnotetext{
* 横浜国立大学工学部（横浜市南区大岡町）
}

晶を得る方法）で精製して用いた。

\section{$2 \cdot 3$ グルコン酸アミド}

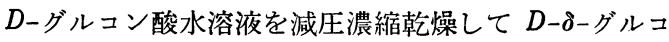
ノラクトンを造り，それをメタノールに溶解しアンモニ アガスを吹込んで $D$-グルコン酸アミドの結晶を得た ${ }^{6,7)}$ 。 その融点は $143^{\circ} \mathrm{C}$ であったから既測定值 ${ }^{8,9)}$ と一致し ている。

\section{4 腐食試験液}

実用乾電池電解液に近い表 1 の溶液を基準液とし，こ

表 1 腐食試験基準液

\begin{tabular}{|c|c|c|c|}
\hline $\begin{array}{l}\text { 組 } \\
\text { 成 }\end{array}$ & & $\begin{array}{l}\mathrm{NH}_{4} \mathrm{Cl} \\
\mathrm{ZnCl}_{2} \\
\mathrm{ZnO} \\
\mathrm{H}_{2} \mathrm{O}\end{array}$ & $\begin{array}{ll}7.2 \mathrm{~mol} & (385 \mathrm{~g}) \\
1.1 \mathrm{~mol} & (150 \mathrm{~g}) \\
0.1 \mathrm{~mol} & (8 \mathrm{~g}) \\
1.00 \mathrm{~kg} & \end{array}$ \\
\hline
\end{tabular}

室温で上記の各成分を混合したときは $\mathrm{pH} か ゙ 5.3$ であったが 50〜 $60^{\circ} \mathrm{C}$ に温めて $\mathrm{ZnO}$ を溶解し $15^{\circ} \mathrm{C}$ に命却したとき 5.8 になった。 比重 $=1.15$, 上記の配合で $1.34 l$ である。

の液およびこれに $\mathrm{HgCl}_{2}$ およびあるいはグルコン酸ア ソモニウム，グルコン酸アミドを添加した液を腐食試験 液として用いた。

\section{3. 腐 食測定法}

$15 \pm 1^{\circ} \mathrm{C}$ の定温のもとに, $2 \phi \times 20 \mathrm{~cm}$ の試験管に 25 $\mathrm{m} l$ の腐食試験液および科量した亜鉛試片を入れ軽く綿 栓をして $1 \sim 30$ 日静置し, 試片を取り出し, 水洗し, 50 ${ }^{\circ} \mathrm{C}$ の $10 \% \mathrm{CrO}_{3}$ 水溶液に 30 秒間浸漬して表面の付着 物を溶解し去り, 水洗し, メタノール洗し, 乾燥後科量 して腐食減量を求めた。

$25 \mathrm{~m} l$ の腐食試験液中の $\mathrm{NH}_{3}$ が全部 $\mathrm{Zn}\left(\mathrm{NH}_{3}\right)_{2}^{2+}$ と なるための所要 $\mathrm{Zn}$ 溶解量は $(7.2 / 2-1.1) \mathrm{mol} \times 0.025 /$ 1.34 すなわち約 $3 \mathrm{~g}$ である。最大腐食減量が $0.04 \mathrm{~g}$ 以 下であったので $\mathrm{Zn}$ 塩の結晶が生成することもなく，ま た試片が完全に液中に浸漬していたので， $25 \mathrm{ml}$ の液量 は適当であった。

亜鉛試片を $50^{\circ} \mathrm{C}$ の $10 \% \mathrm{CrO}_{3}$ 水溶液に浸漬するた めの重量減は $0.2 \mathrm{mg} / \mathrm{cm}^{2}$ 以下で無視できた。

一度測定した試片は $\mathrm{CrO}_{3}$ により表面に耐食性被膜が 
できていることも考えられるので再び腐食試験には用い なかった。

試片の減量と腐食時間との関係は多数の実験を行なっ て求めた。

\section{4. 腐食試験結果}

腐食試験基準液およびこれに防食剂を加えた液を用い て測定し，亜鉛試片の単位面積当りの腐食減量と腐食時 間との関倸を求め図 1 を得た。

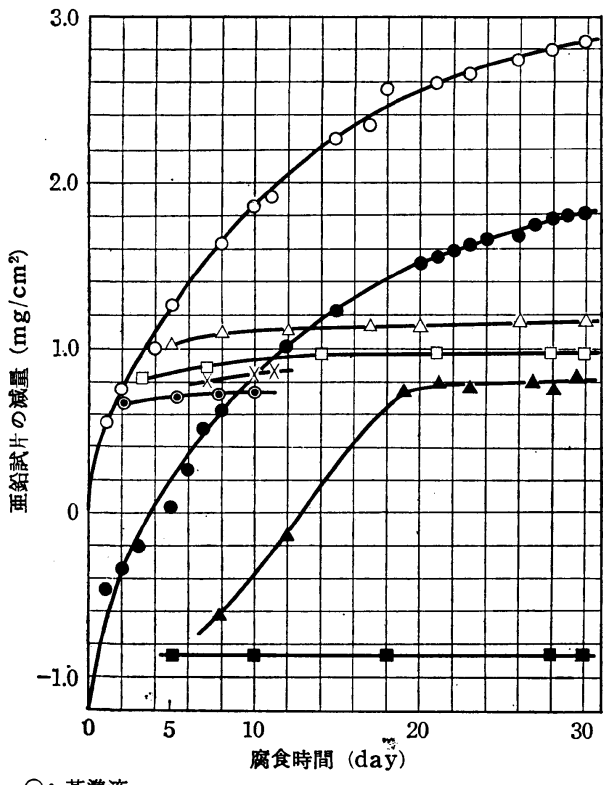

$\bigcirc$ : 基準液

$\triangle: 0.0013$ molal ク゚ルコン酸アンモニウム十基準液

口: 0.004 molal グルコン酸アンモニウム十基準液

$\times: 0.0013$ molal グルコン酸アミド+基準液

O: 0.007 molal クルルコン酸フミド+基準液

: 0.006 molal $\mathrm{HgCl}_{2}+$ 基準液

$\Delta$ : 0.006 molal $\mathrm{HgCl}_{2}+0.013 \mathrm{molal}$ グルコン䤇フンモニウ 厶十基準液

: 0.006 molal $\mathrm{HgCl}_{2}+0.13$ molal グルコン酸 アンモニウ 么十基準液

図 1 各腐食試験液中における亜鉛の腐食減量と腐 食時間との関係 $\left(15 \pm 1^{\circ} \mathrm{C}\right)$

$\mathrm{HgCl}_{2}$ を添加した液では $\mathrm{Zn}+\mathrm{Hg}^{2+}=\mathrm{Zn}^{2+}+\mathrm{Hg}$ によ り亜鉛試片上にアマルガムができ，そのための試片の重 量増加は $(200.59-63.57) \times 0.006 \times(0.025 / 1.34) \mathrm{g}$ すな わち $15 \mathrm{mg}\left(1.2 \mathrm{mg} / \mathrm{cm}^{2}\right)$ である。

図 1 では重量増加が負で表わされているから， $\mathrm{HgCl}_{2}$ 添加の液による腐食減量は曲線の示寸值に $1.2 \mathrm{mg} / \mathrm{cm}^{2}$ を加えた值である。

この腐食試験液と市販乾電池電解液とを比較すれば, $\mathrm{HgCl}_{2}$ 濃度は大差がないが，亜鉛の単位面積当りおよび 単位重量当りの液量したがって $\mathrm{Hg}$ 量は前者が後者の数 倍である。亜鉛の腐食，強さの減少などに関する $\mathrm{Hg}$ の 影響は带鉛単位面積当りあるいは単位重量当りの $\mathrm{Hg}$ 量 に関係するもの之考えられる。ゆえにこの $\mathrm{HgCl}_{2}$ 添加 液による腐食試験結果は市販乾電池の場合にそのまま当
てはまらないであろう。しかしグルコン酸フンモニウ ム，グルコン酸てミドなどの亜鉛防食効果の試験結果に ついては両者において同様な傾向が現われるものと考元 てよかろう。

図 1 から，一般に最初の $1 \sim 2$ 日の腐食減量が大きい が，これは試片の表面が細かい粗面である，表面の薄層 に加工残留ひずみがある，グルコン酸フンモニウム，グ ルコン酸アミドなどによる防食力が最大になるのに若干 の時間がかかる，その他の理由によるものと考えられ る。

腐食試験基準液およびこれに 0.006 molal $の \mathrm{HgCl}_{2}$ を加えた液では亜鉛試片の腐食速度が初め大きく，経時 的に小さくなって行くが, 20〜30 日においてもなお腐食 が進んで行く。

基準液に $0.001 \sim 0.004 \mathrm{molal}$ のグルコン酸フンモニ ウムあるいは 0.001 0.007 molal のグルコン酸アミド を加えた溶液では亜鉛試片の腐食が初期の $1 \sim 4$ 日は基 準液と同程度に進行したが，5 日以後は著しく減退し， 10 日以後はほとんど進行しなくなった。

基準液に 0.006 molal $の \mathrm{HgCl}_{2}$ と $0.013 \mathrm{molal}$ の グルコン酸フンモニウムとを添加した溶液では亜鉛試片 の腐食が初期の 19 日間は進行したが，20〜30 日の間に はほとんど進行しなかった。

基準液に 0.006 molal の $\mathrm{HgCl}_{2}$ と 0.13 molal のグ ルコン酸アンモニウムとを添加した溶夜では亜鉛試片の 腐食が初期の $1 \sim 4$ 日間はわずかに進行したが，5 日以 後はほとんど進行しなかった。

各溶液による亜鉛試片の腐食を比較すれば，基準液に 0.006 molal $\left(1.6 \mathrm{~g} / \mathrm{kg} \mathrm{H}_{2} \mathrm{O}\right)$ の $\mathrm{HgCl}_{2}$ と 0.13 molal $\left(28 \mathrm{~g} / \mathrm{kg} \mathrm{H}_{2} \mathrm{O}\right)$ のグルコン酸アンモニウムを加えた液が 最も少なく，基準液に $0.001 \sim 0.004$ molal $(0.2 \sim 0.9$ $\left.\mathrm{g} / \mathrm{kg} \mathrm{H}_{2} \mathrm{O}\right)$ のグルコン酸アンモニウムまたは 0.001 0.007 molal $\left(0.2 \sim 1.4 \mathrm{~g} / \mathrm{kg} \mathrm{H}_{2} \mathrm{O}\right)$ のグルコン酸アミド を加えた液は基準液あるいはこれに 0.006 molal の $\mathrm{HgCl}_{2}$ を加えた液より少ない。

現在実用されている亜鉛二酸化マンガン乾電池の極微 酸性電解液は基準液に 0.006 molal の $\mathrm{HgCl}_{2}$ を加えた ものに近い組成の液にデンプンが加えられ糊化されたも のである。デンプンの添加および糊化により亜鉛陰極の 腐食がかなり防がれている3が， $\mathrm{HgCl}_{2}$ を含有するから 覀鉛陰極に水銀が析出しアマルガムとなるので，陰極の 強さが劣化する欠点がある。ゆえに, $\mathrm{HgCl}_{2}$ を添加しな いでグルコン酸アンモニウムおよびあるいはグルコン酸 アミドを添加した亜鉛陰極の腐食が少なく，上記の欠点 のない電解液を電池に利用する研究が望まれる。

\section{5. 結言}

亜鉛二酸化マンガン乾電池の極微酸性電解液に近い組 
成でデンプンを含有しない液（表 1 の液）に亜鉛の防食 戍として，(a) 0.006 molal の $\mathrm{HgCl}_{2}$ と 0.13 molal の グルコン酸アンモニウム，(b) $0.0013 \sim 0.007$ molal の グルコン酸アミド，(c) $0.0013 \sim 0.004$ molal のグルコ ソ酸アンモニウム，(d) 0.006 molal の $\mathrm{HgCl}_{2}$ などを添 加して亜鉛の腐食を測定し，次の結果を得た。

(1) (a), (b), (c) の防食効果浽顕著である。

(2) 防食効果の大>小の順は次のとおりである。 (a) $>$ (b) $>$ (c) $\gg$ (d)

\section{感謝}

ご後援を頂いた日立マクセル株式会社および同社取締 役工学博士鎌居利惣氏に梁甚な謝意を表する。 (昭和 39 年 3 月 30 日受理)
文献

1) C. K. Morehouse, W. J. Hamer \& G. W. Vinal: $J$. Research NBS, 40, 151 (1948)

2) E. M. Klopp, J. Rischel \& K.S. Willson; Proc. 11th Ann. Bat. Res. Dev. Conf. p. 32 (1957)

3) 高橋樟彦: 電化, 26, 597 (1958)

4) H. M. Zimmerman \& R. A. Powers: U. S. Pat. 2,900, 434 (1959)

5) 平井竹次, 福田雅太郎：電化, 30, 118 (1962)

6) C.S. Hudson \& S. Komatsu: J. Am. Chem. Soc., 41, 1141 (1919)

7) J. K. N. Jones: Can. J. Chem., 34, 310 (1956)

8) I. M. Heibon: Dictionary of Organic Compounds, Vol. 2, 114 (1936)

9) F. Richter: Beilsteins Handbuch der Organischen Chemie, 4. Aufl., 1. Erg., p. 189 (1929), Julius Springer, Berlin.

\section{NACE 腐食用語集 (1)}

\section{Aeration Cell}

See Differential Aeration Cell

\section{Aggressive Carbon Dioxide}

Free carbon dioxide in excess of the amount necessary to prevent precipitation of calcium as calcium carbonate.

\section{Anaerobic}

Free of uncombined oxygen.

\section{Anion}

A negatively charge ion or radical which migrates toward the anode under the influence of a poten. tial gradient.

\section{Anode}

The electrode of an electrolytic cell at which a net oxidation reaction occurs. In corrosion processes, the anode is the electrode that has the greater tendency to go into solution.

\section{Anode Corrosion Efficiency}

The ratio of the actual corrosion of an anode to the theoretical corrosion calculated from the quantity of electricity which has passed.

\section{Anodic Polarization}

That portion of the polarization of a cell which occurs at the anode.

\section{Anolyte}

The electrolyte of an electrolyte cell adjacent to the anode.
The face-centered cubic crystal structure of ferrous metals.

\section{Cathode}

The electrode of an electrolytic cell at which a net reduction reaction occurs. In corrosion processes, the cathode is usually the area that is not attacked.

\section{Cathodic Corrosion}

An increase in corrosion of a metal by making it cathodic.

\section{Cathodic Polarization}

That portion of the polarization of a cell which occurs at the cathode.

\section{Cathodic Protection}

Reduction or prevention of corrosion of a metal surface by making it cathodic, for example, by the use of sacrificial anodes or impressed currents.

\section{Catholyte}

The electrolyte of an electrolytic cell adjacent to the cathode.

\section{Cation}

A positively charged ion or radical which migrates toward the cathode under the influence of a potential gradient.

\section{Caustic Embrittlement}

Embrittlement of a metal resulting from contact with an alkaline solution.

Corrosion, 20, No. 8, 267 t 68 t (1964) Aug. 